\title{
The Relationship between Job Burnout and Gender-Based Socio-Demographic Characteristics in Lahore
}

\section{Shamila Nabi Khan*}

\begin{abstract}
Job burnout has been extensively researched in the international literature. Burnout is caused by personal and occupational factors. This study analyzes the impact of burnout with respect to different socio-demographic characteristics and job-related factors. Based on a sample randomly selected from various industries in the Lahore region, we use cross-tabulations to analyze the effects of burnout, and calculate the mean frequencies of the variables used. We measure three dimensions of burnout-emotional exhaustion, cynicism, and lack of personal accomplishment-using the Maslach Burnout Inventory-General Survey. The study finds that women score significantly on emotional exhaustion while men score higher on cynicism and lack of personal accomplishment, compared to all other socio-demographics. Education and work experience are strongly associated with burnout in women while age and income are significantly related to burnout in men. Women's higher burnout scores are related to higher levels of education (graduates), less work experience (0-10 years), income (PKR 10,000-25,000), age (24-35 years), being self-employed, and working in the manufacturing industry. Among men, burnout is associated with white-collar (upper and lower) employee positions, work experience of 0-4 years, incomes of PKR 25,000 or more, and working in the services industry. Burnout is more significant among men than women with regard to marital status. Among job stressors, men and women are not significantly different with respect to role ambiguity, role conflict, organizational politics, autonomy, and work overload. Most of our results confirm the findings of other studies on job burnout, with the exception that the male respondents in this study experienced high burnout at an early age (24-29-yearold category), which could be due to 'reality shocks' or 'early career burnout'.
\end{abstract}

Keywords: Burnout, emotional exhaustion, cynicism, personal efficacy.

JEL classification: M12, J16.

\footnotetext{
* The author is a teaching fellow at the Lahore School of Economics, and can be contacted at shamilankhan@hotmail.com.
} 


\section{Introduction}

\subsection{Defining burnout}

An individual's job and working environment can create mental tension and stress. Common symptoms of mental disorders are anxiety, depression, and reduced self-esteem, while physical disorders can include headaches and stomachaches, and increase one's future risk of frequent illness (Yip \& Rowlinson, 2007). Prolonged exposure to these symptoms can produce a number of negative effects such as reduced productivity, impaired performance, low levels of customer service, absenteeism, turnover, and other social problems (Van der Colff \& Rothmann, 2009).

Burnout is a type of stress response most commonly displayed by individuals who have direct and intense contact with students, clients, or patients. It may arise when an individual tries to accomplish too much in too little time as a result of unrealistic deadlines, too many meetings or projects, and high expectations. While stress is not bad per se, all people have their limits and once they reach these limits, burnout is likely. Thus, job burnout is a psychological syndrome that involves a prolonged response to stressors in the workplace.

The term 'burnout' was coined by Freudenberger (1974), who observed that employees who came to the workplace motivated and interested in their jobs soon lost the energy and morale needed to cope with professional demands. The Maslach Burnout Inventoy (MBI) defines burnout as "a syndrome of emotional exhaustion, depersonalization, and reduced personal accomplishment that can occur among individuals who do 'people work' of some kind" (Maslach, Schaufeli, \& Leiter, 2001).

A widely accepted model, the MBI holds that burnout is characterized by three interrelated dimensions. The first-and a key component of burnout syndrome-is an increased feeling of emotional exhaustion. At this stage, the individual feels mentally drained and 'empty' or 'worn out'. Since his/her emotional resources are depleted, he/she is unable to perform as best possible. The second dimension is the development of negative, cynical feelings toward one's work or the recipients of one's services (Maslach \& Jackson, 1986). The third aspect of the burnout syndrome is the tendency to evaluate oneself negatively with respect to one's work with clients (Jackson, Turner, \& Brief, 1987). Several studies confirm these three phases of burnout (Cordes \& Dougherty, 1993; Koeske \& Koeske, 1989; Tripathy, 2002). 
Initially, burnout was seen as occurring solely within "helping" professions such as nursing and education because Maslach et al. (2001) considered burnout to be a helper's syndrome resulting from emotionally demanding relationships with clients. Such relationships are inherently difficult because human services professionals deal with troubled people who suffer and are in need. The former are likely to feel emotionally exhausted, to treat their clients as objects, and sometimes to even doubt their professional competence when dealing with clients. The introduction of the MBI-General Survey (MBI-GS) has, however, made it possible to measure the three dimensions independently of the services professional context (Maslach et al., 2001). Psychometrically, MBI-GS works well and has proven its validity and reliability in many countries, including the US, UK, Finland, and Spain, and across samples of office workers in occupations other than the services sector (Koeske \& Koeske, 1989).

The purpose of this study is to explore the relationship between socio-demographic characteristics-including age, gender, and education, type of employment, work experience, time spent working, industry, and marital status - and the three levels of burnout in the Lahore region. Some of the organizational factors we include are work overload, role ambiguity, role conflict, organizational politics, and autonomy.

\subsection{Research Questions}

The study seeks to answer the following questions:

- What organizational and job factors (type of job, work experience, working arrangements, working hours, type of sector, and industry) predict the level of burnout in males and females?

- What individual factors (age, marital status, education, income, and occupational level) best predict the level of burnout in males and females?

- How do job stressors (role ambiguity, role conflict, work overload, organizational politics, autonomy, job security, and mental stimulation at work) affect gender and the level of burnout?

\section{Literature Review}

A stressful work environment that offers little or no opportunity for personal growth, has an overwhelming workload, and offers little or no support, can lead to burnout (Masalch et al., 2001). Other work environment-related factors leading to burnout include role conflict, 
ambiguity, autonomy, lack of opportunity to participate in decisionmaking, and lack of control over one's job. Burnout is caused by organizational as well as individual factors. (Cherniss, 1993; Maslach \& Schaufeli, 1993). This study explores both the individual and occupational factors that promote burnout.

\subsection{Organizational Factors}

Overload is the perception that there is too much work to complete in the given time; qualitative overload occurs when a worker's job requirements exceed his/her skill level (Sanders, Fulks, \& Knoblett, 1995). Work overload drains the individual of emotional resources and energy, causing emotional exhaustion (Schaufeli, Leiter, \& Maslach, 2008) - the first of the three components of burnout. Maslach et al. (2001) confirm that workload and time pressure are consistently and strongly related to job burnout.

Role conflict and role ambiguity are both precursors of burnout. As described by Rizzo, House, and Lirtzman (1970), role conflict occurs when an employee perceives a discrepancy between the expectations conveyed by different sources, while role ambiguity occurs when an employee is uncertain about his/her professional expectations. While earlier research established that role conflict and role ambiguity had an independent, direct causal relationship with burnout (Jackson, 1983), Kirk-Brown and Wallace (2004), in a study on workplace counselors, find that role ambiguity alone (and not role conflict) is a significant predictor of burnout.

Lack of autonomy, also described as lack of participation in decision-making, has also been shown to cause worker exhaustion (Maslach et al., 2001; Pines, Aronson, \& Kafry, 1981). Lack of autonomy implies an uncontrollable environment; when employees feel that their environment is sufficiently uncontrollable, they resort to depersonalizing their relationships (Jackson et al., 1987). Cordes and Dougherty (1993) confirm that employees who work in impersonal, bureaucratic, rigid, or controlled work environments experience a higher level of burnout.

Interpersonal conflict has also been identified as a strong predictor of burnout, with some studies indicating that interaction with coworkers is the single most important source of job burnout (Schaufeli et al., 2008). According to Leiter and Maslach (2004), interpersonal contact can often be negative because of conflicts over organizational policies, conflicting personal values, or disagreements about how a job should be carried out. They also find that negative contact is linked to increased emotional 
exhaustion, depersonalization, and decreased professional efficacy-all three components of burnout.

\subsection{Socio-Demographic Factors}

An additional aim of this research is to explore the relationship between socio-demographic characteristics-including age, gender, education, type of employment, work experience, time spent working, industry, and marital status-and burnout (Ahola, Honkonen, Isometsä, Kalimo, Nykyri, Koskinen et al., 2005). Many studies show that age is the most consistently related to burnout (Birch, Marchant, \& Smith, 1986; Mor \& Laliberte, 1984; Poulin \& Walter, 1993; Bakker, Demerouti, \& Schaufeli, 2002). Although burnout is observed more often among those aged over 30-40 years, other research suggests that burnout can also occur in younger professionals, explained by 'early career burnout' and 'reality shocks' (Cherniss, 1980). The MBI manual shows a decline in burnout levels with age or work experience for all three dimensions (Maslach, Jackson, \& Leiter, 1996).

The relationship between burnout and gender is not so clear-cut. Some studies show that burnout occurs more often among females than among males (Maslach \& Jackson, 1981; Poulin \& Walter, 1993), while others argue the opposite (Burke, Greenglass, \& Schwarzer, 1996; Price \& Spence, 1994; Van Horn, Schaufeli, Greenglass, \& Burke, 1997). However, females score higher on emotional exhaustion, while males score higher on depersonalization (Vredenburgh, Carlozzi, \& Stein, 1999; Schaufeli \& Enzmann, 1998). According to Schaufeli and Enzmann (1998), being unmarried and more highly educated carries a greater burnout risk. Burnout has also been extensively investigated in services-based industries especially healthcare and teaching (Schaufeli \& Buunk, 2005; Gundersen, 2001; Rutter, Herzberg, \& Paice, 2002).

Marital status is significantly related to emotional exhaustion. In Maslach et al. (2001), people who were single or divorced scored higher than married people. We also find differences in the level of education for each of the MBI subscales. Higher education levels are associated with higher scores for emotional exhaustion while the reverse occurs for depersonalization, which is lowered by higher education levels. Graduates are found to score higher on personal accomplishments. The role of sociodemographic factors is, however, neither strong nor consistent. The most consistent and methodologically valid results relate burnout to workrelated and organizational factors. 
Geurts, Rutte, and Peeters (1999) and Sargent, Sotile, Sotile, Rubash, and Barrack (2004) find that longer working hours are associated with higher burnout among medical residents. Employees in social welfare tend to experience more burnout than those in education, healthcare, banking, industry, and the postal service (Matthews, 1999). Several studies have been carried out on burnout in healthcare (Felton, 1998) and education (Brouwers \& Tomic, 2000; Burke et al., 1996; Mazur \& Lynch, 1989), where the burnout level was higher than in other occupations. Among white-collar and blue-collar employees, there were no differences in the process or causes of burnout (job stressors) (Toppinen-Tanner, Kalimo, \& Mutanen, 2002).

\section{Methodology}

\subsection{Study Design}

Our research design included a questionnaire on individual and job-related factors that was self- administered by the survey's respondents. The sample consisted of employees in organizations randomly chosen from the healthcare, education, manufacturing, and services industries in Lahore. Of 100 questionnaires that were given out, 11 were discarded because of missing or incomplete information. The questionnaire included the MBI-GS, assessed using a Likert scale rating.

\subsection{Measures}

Emotional exhaustion occurs when an individual feels completely drained and loses control of his or her emotions (Maslach et al., 2001). It has physical, emotional, intellectual, and social elements. In this study, we use the emotional exhaustion subscale of the MBI-GS to measure exhaustion. We define cynicism as the indifference of a worker as he/she depersonalizes his/her work. Given that the literature on burnout uses the term cynicism interchangeably with depersonalization, we use the cynicism subscale of the MBI-GS to measure depersonalization.

Professional inefficacy refers to a worker's perception that he/she is a failure and/or has few feelings about his/her accomplishments and/or competence. In the literature, professional inefficacy is used interchangeably with lack of personal accomplishment. In this study, we measure inefficacy on the professional efficacy subscale of the MBI-GS. The items are scored on a seven-point scale ranging from 1 (a few times a year) to 6 (everyday). The percentile scores of emotional exhaustion, cynicism, 
and personal efficacy identify high, moderate, and low burnout scores. High scores on exhaustion and cynicism and low scores on professional efficacy are indicative of burnout.

Role ambiguity, role conflict, work overload, organizational politics, and autonomy are assessed using a Likert-scale rating. The other variables used are gender, age, level of basic and vocational education, working time arrangements, number of hours worked per week, marital status, and industry.

Gender is divided into male and female. Marital status is divided into married and unmarried (including widowed, divorced, or single). Basic education is classified into below secondary, secondary to intermediate, and graduate. Vocational education is classified as one course or less, school, institution, or higher education. Socioeconomic status comprises income and occupational level, where the latter is defined as self-employed, upper white-collar, lower white-collar, and blue-collar. Classification of income also defines the level of occupation with income intervals.

Working time arrangements include regular day jobs, regular evening/night jobs, shift work, and others. Weekly hours are classified as part-time (less than 37 hours), normal (37-40 hours), regular overtime (4154 hours), or abundant overtime (55-70 hours). Types of employees are defined by the sector in which they work in-public or private. Working industries are classified as education (teachers), health (doctors and nurses), manufacturing (managers, staff members), services (banking, logistics), or others. The distribution of the continuous variables age and work experience are portioned into five equal parts at a 20 percent interval.

\subsection{Sample Composition}

The final study sample comprised 89 workers, after 11 questionnaires were eliminated on the grounds of incomplete data. Out of 89, 55 (61 percent) were male and 34 (38 percent) female. The largest age group included young adults aged 24-29 (47.2 percent). Fifty percent of the participants were married and about the same were unmarried. More than half the participants were university graduates (70 percent). Thirty percent of the respondents earned PKR 40,000, while 32 percent earned PKR 10,000-25,000. Forty-seven percent were classified as lower white-collar employees, 21 percent as upper white-collar, 17 percent as self-employed, and 14 percent as blue-collar employees. About 37 percent had 0-4 years' 
work experience, followed by 24 percent with 5-10 years' experience. Thirty percent worked in the public sector while 70 percent belonged to the private sector. Within industries, 30 percent worked in manufacturing, 24 percent in services, 15 percent in banking, 12 percent in education, 10 percent in social services, and 5 percent in hospitals.

\subsection{Research Hypotheses}

Overwhelmingly, the literature supports the conceptualization of burnout as a three-component construct. Emotional exhaustion, cynicism (depersonalization), and the perception of professional inefficacy (lack of personal accomplishment) are repeatedly demonstrated to be the three dimensions of burnout. Studies on burnout consistently consider the phenomenon by measuring these three variables. The null hypotheses formulated for this study are as follows:

- Hypothesis 1: There is no significant relationship between gender and burnout.

- Hypothesis 2: There is no significant relationship between age, level of burnout, and gender.

- Hypothesis 3: There is no significant relationship between education, level of burnout, and gender.

- Hypothesis 4: There is no significant relationship between working status, level of burnout, and gender.

- Hypothesis 5: There is no significant relationship between work experience, level of burnout, and gender.

- Hypothesis 6: There is no significant relationship between marital status, level of burnout, and gender.

- Hypothesis 7: There is no significant relationship between household income, level of burnout, and gender.

- Hypothesis 8: There is no significant relationship between sector, level of burnout, and gender.

- Hypothesis 9: There is no significant relationship between industry, level of burnout, and gender.

- Hypothesis 10: There is no significant relationship between role ambiguity and gender.

- Hypothesis 11: There is no significant relationship between role conflict and gender. 
- Hypothesis 12: There is no significant relationship between work overload and gender.

- Hypothesis 13: There is no significant relationship between organizational politics and gender.

- Hypothesis 14: There is no significant relationship between autonomy and gender.

\section{Statistical Analysis}

The data was analyzed using SPSS 10, applying cross-tabulations to analyze the effects of burnout. Socioeconomic factors and stressors are treated as independent variables while burnout variables are treated as dependent variables. We calculate the means frequencies of all the variables, followed by the cross-means between the level of burnout, gender, and other socio-demographic factors. Since burnout is a combination of three aspects, we generate three tables to discuss each hypothesis. Differences between genders are analyzed in percentages. An observed $\mathrm{N}$ is excluded to eliminate the possibility of bias between greater or fewer observations of any specific variable, easing the analysis. Chisquares are used to analyze the significance of the cross-tabulations.

\subsection{Data Analysis}

Table 1 shows that most males (63.6 percent) and females (67.5 percent) felt their jobs were secure; 11.8 percent of females and 12.7 percent of males thought their jobs were not secure. Twenty-two percent of the total sample gave no opinion about their job security. An overwhelming majority of respondents ( 96.4 percent of females and 94.1 percent of males) said they felt respected at work, while 2.9 percent of females felt they were not. Around 65.5 percent of males and 67.6 percent of females said they were mentally stimulated at work, while 18.2 percent of males and 14.7 percent of females said they were not. The chi-square is insignificant for job security, respect at work, and mental stimulation at work ( $p>0.005)$. 
Table 1: Gender cross-tabulation

\begin{tabular}{|c|c|c|c|c|}
\hline Response & & Males (\%) & Females (\%) & Total (\%) \\
\hline \multirow[t]{3}{*}{ I feel that my job is secure } & Yes & 63.6 & 67.6 & 65.2 \\
\hline & No opinion & 23.6 & 20.6 & 22.5 \\
\hline & No & 12.7 & 11.8 & 12.4 \\
\hline \multirow[t]{2}{*}{ Total } & & 100.0 & 100.0 & 100.0 \\
\hline & & Chi-square & 0.926 & \\
\hline \multirow[t]{3}{*}{ I feel respected at work } & Yes & 96.4 & 94.1 & 95.5 \\
\hline & No opinion & 3.6 & 2.9 & 3.4 \\
\hline & No & & 2.9 & 1.1 \\
\hline \multirow[t]{2}{*}{ Total } & & 100.0 & 100.0 & 100.0 \\
\hline & & Chi-square & 0.436 & \\
\hline \multirow[t]{3}{*}{ I feel stimulated at work } & Yes & 65.5 & 67.6 & 66.3 \\
\hline & No opinion & 16.4 & 17.6 & 16.9 \\
\hline & No & 18.2 & 14.7 & 16.9 \\
\hline \multirow[t]{2}{*}{ Total } & & 100.0 & 100.0 & 100.0 \\
\hline & & Chi-square & 0.911 & \\
\hline
\end{tabular}

Source: Author's calculations.

Hypothesis 1: There is no significant relationship between gender and burnout.

Table 2 shows that, in the first phase of burnout, 23.5 percent of females and 3.6 percent of males score high on emotional exhaustion. Cynicism or depersonalization is high among 12.7 percent of males compared to 2.9 percent of females. In the last phase of burnout, lack of personal accomplishment is higher among males (23.6 percent) than females (17.6 percent). The chi-square is significant for emotional exhaustion $(\mathrm{p}=0.001)$ but insignificant for cynicism and personal efficacy ( $\mathrm{p}=0.632$ and 0.794 , respectively). 
Table 2: Burnout * gender cross-tabulation

\begin{tabular}{|c|c|c|c|c|}
\hline Response & & Males (\%) & Females (\%) & Total (\%) \\
\hline \multirow{3}{*}{$\begin{array}{l}\text { Emotional } \\
\text { exhaustion }\end{array}$} & High & 3.6 & 23.5 & 11.2 \\
\hline & Moderate & 34.5 & 50.0 & 40.4 \\
\hline & Low & 61.8 & 26.5 & 48.3 \\
\hline \multirow[t]{2}{*}{ Total } & & 100.0 & 100.0 & 100.0 \\
\hline & & Chi- square: & 001 & \\
\hline \multirow[t]{3}{*}{ Cynicism } & High & 12.7 & 2.9 & 9.0 \\
\hline & Moderate & 29.1 & 20.6 & 25.8 \\
\hline & Low & 58.2 & 76.5 & 65.2 \\
\hline \multirow[t]{2}{*}{ Total } & & 100.0 & 100.0 & 100.0 \\
\hline & & Chi-square: & & \\
\hline \multirow{3}{*}{$\begin{array}{l}\text { Personal } \\
\text { accomplishment }\end{array}$} & High & 23.6 & 17.6 & 21.3 \\
\hline & Moderate & 58.2 & 61.8 & 59.6 \\
\hline & Low & 18.2 & 20.6 & 19.1 \\
\hline \multirow[t]{2}{*}{ Total } & & 100.0 & 100.0 & 100.0 \\
\hline & & Chi-square: & & \\
\hline
\end{tabular}

Source: Author's calculations.

Hypothesis 2: There is no significant relationship between age, level of burnout, and gender.

As Table 3 shows, emotional exhaustion is high among males aged 24-29 years (11.1 percent), and among females aged 24-28 years (20.8 percent), 30-35 years (33.3 percent), and 36-41 years (20.0 percent). It is highest among females aged $48-52$ years (50.0 percent). The opposite is true for cynicism, which is highest among males aged 24-29 years (33.3 percent), followed by those aged 30-41 years (14.3 percent) and $42-47$ years (11.1 percent). Among females, cynicism is high among those aged 24-29 years (12.5 percent) and the middle-age category (48-52 years). Lack of personal accomplishment becomes higher after 42-64 years. Among females, lack of personal accomplishment is higher among 30-35-year-olds (33.3 percent) than 24-29-year-olds (20.8 percent). The chi-square is significant for males for cynicism and personal efficacy. 
Table 3: Burnout * gender cross-tabulation

\begin{tabular}{|c|c|c|c|c|c|c|c|c|c|}
\hline \multirow{2}{*}{\multicolumn{3}{|c|}{ Percentage by age }} & \multicolumn{6}{|c|}{ Age (years) } & \multirow[b]{2}{*}{ Total } \\
\hline & & & \multirow{2}{*}{$\begin{array}{r}24-29 \\
11.1\end{array}$} & \multirow[t]{2}{*}{$30-35$} & \multirow[t]{2}{*}{$36-41$} & \multirow[t]{2}{*}{$42-47$} & \multirow[t]{2}{*}{$48-52$} & \multirow[t]{2}{*}{$53-64$} & \\
\hline \multirow[t]{5}{*}{ Males } & \multirow{3}{*}{$\begin{array}{l}\text { Emotional } \\
\text { exhaustion }\end{array}$} & High & & & & & & & 11.2 \\
\hline & & Moderate & 44.4 & 57.1 & 57.1 & & 20.0 & 25.0 & 40.4 \\
\hline & & Low & 44.4 & 42.9 & 42.9 & 100.0 & 80.0 & 75.0 & 48.3 \\
\hline & \multirow{2}{*}{\multicolumn{2}{|c|}{ Total }} & 100.0 & 100.0 & 100.0 & 100.0 & 100.0 & 100.0 & 100.0 \\
\hline & & & \multicolumn{6}{|c|}{ Chi-square: 0.113} & \\
\hline \multirow[t]{5}{*}{ Females } & \multirow{3}{*}{$\begin{array}{l}\text { Emotional } \\
\text { exhaustion }\end{array}$} & High & 20.8 & 33.3 & 20.2 & & 50.0 & & 23.5 \\
\hline & & Moderate & 54.2 & 33.3 & 40.0 & & 50.0 & & 50.0 \\
\hline & & Low & 25.0 & 33.3 & 40.0 & & & & 26.5 \\
\hline & \multirow{2}{*}{\multicolumn{2}{|c|}{ Total }} & 100.0 & 100.0 & 100.0 & & 100.0 & 100.0 & 100.0 \\
\hline & & & \multicolumn{4}{|c|}{ Chi-square: 0.909} & & & \\
\hline \multirow[t]{5}{*}{ Males } & \multirow[t]{3}{*}{ Cynicism } & High & 33.3 & 14.3 & 14.3 & 11.1 & & & 16.4 \\
\hline & & Moderate & 50.0 & 14.3 & 14.3 & 11.1 & 30.0 & 25.0 & 29.1 \\
\hline & & Low & 16.7 & 71.4 & 71.4 & 77.8 & 70.0 & 75.0 & 54.5 \\
\hline & \multirow{2}{*}{\multicolumn{2}{|c|}{ Total }} & 100.0 & 100.0 & 100.0 & 100.0 & 100.0 & 100.0 & 100.0 \\
\hline & & & \multicolumn{4}{|c|}{ Chi-square: 0.063} & & & \\
\hline \multirow[t]{5}{*}{ Females } & \multirow[t]{3}{*}{ Cynicism } & High & 12.5 & & & & 50.0 & & 11.8 \\
\hline & & Moderate & 25.0 & 33.3 & 20.0 & & & & 23.5 \\
\hline & & Low & 62.5 & 66.7 & 80.0 & & 50.0 & & 64.7 \\
\hline & \multirow{2}{*}{\multicolumn{2}{|c|}{ Total }} & 100.0 & 100.0 & 100.0 & & 100.0 & & 100.0 \\
\hline & & & \multicolumn{4}{|c|}{ Chi-square: 0.630} & & & \\
\hline \multirow[t]{5}{*}{ Males } & \multirow{3}{*}{$\begin{array}{l}\text { Personal } \\
\text { accomplishment }\end{array}$} & High & 11.1 & & & 55.6 & 40.0 & 50.0 & 23.6 \\
\hline & & Moderate & 66.7 & 57.1 & 85.7 & 22.2 & 60.0 & 50.0 & 58.2 \\
\hline & & Low & 22.2 & 42.9 & 14.3 & 22.2 & & & 18.2 \\
\hline & \multirow{2}{*}{\multicolumn{2}{|c|}{ Total }} & 100.0 & 100.0 & 100.0 & 100.0 & 100.0 & 100.0 & 100.0 \\
\hline & & & Chi-squ & lare: 0.0 & & & & & \\
\hline Females & Personal & High & 20.8 & 33.3 & & & & & 17.6 \\
\hline & accomplishment & Moderate & 62.5 & 33.3 & 60.0 & & 100.0 & & 61.8 \\
\hline & & Low & 16.7 & 33.3 & 40.0 & & & & 20.6 \\
\hline & Total & & 100.0 & 100.0 & 100.0 & & 100.0 & & 100.0 \\
\hline & & & Chi-squ & Iare: 0.6 & & & & & \\
\hline
\end{tabular}

Source: Author's calculations.

Hypothesis 3: There is no significant relationship between education, level of burnout, and gender.

This hypothesis relates education to the level of burnout between genders. Table 4 shows that, among males, graduates report high emotional exhaustion (5.7 percent). Among females, graduates (24.1 percent) as well as those with below secondary-level education (25.0 percent) report high emotional exhaustion. Male graduates (22.9 percent) and those with below secondary-level education (11.1 percent) score high 
on cynicism, as do female graduates (6.9 percent) and those with below secondary-level education (50.0 percent). In the lack of personal accomplishment category, males with below secondary-level education score highest (55.6 percent), followed by secondary to intermediate (36.4 percent) and graduates (11.4 percent). Female graduates score high on lack of personal accomplishment (20.7 percent). The chi-square term is significant for males for cynicism and personal efficacy.

\section{Table 4: Burnout * education * gender cross-tabulation}

\begin{tabular}{|c|c|c|c|c|c|c|}
\hline \multirow{2}{*}{\multicolumn{2}{|c|}{ Percentage within education }} & & \multicolumn{3}{|c|}{ Education } & \multirow[b]{2}{*}{ Total } \\
\hline & & & \multirow[t]{2}{*}{$\begin{array}{c}\text { Below } \\
\text { secondary }\end{array}$} & \multirow[t]{2}{*}{ Secondary } & \multirow{2}{*}{$\begin{array}{c}\text { Graduate } \\
5.7\end{array}$} & \\
\hline \multirow[t]{5}{*}{ Males } & Emotional & High & & & & 3.6 \\
\hline & exhaustion & Moderate & 11.1 & 36.4 & 40.0 & 34.5 \\
\hline & & Low & 88.9 & 63.6 & 54.3 & 61.8 \\
\hline & Total & & 100.0 & 100.0 & 100.0 & 100.0 \\
\hline & & & \multicolumn{3}{|c|}{ Chi-square: 0.369} & \\
\hline \multirow[t]{5}{*}{ Females } & Emotional & High & 25.0 & & 24.1 & 23.5 \\
\hline & exhaustion & Moderate & 75.0 & 100.0 & 44.8 & 50.0 \\
\hline & & Low & & & 31.0 & 26.5 \\
\hline & Total & & 100.0 & 100.0 & 100.0 & 100.0 \\
\hline & & & \multicolumn{3}{|c|}{ Chi-square: 0.566} & \\
\hline \multirow[t]{5}{*}{ Males } & Cynicism & High & 11.1 & & 22.9 & 16.4 \\
\hline & & Moderate & & 45.5 & 31.4 & 29.1 \\
\hline & & Low & 88.9 & 54.5 & 45.7 & 54.5 \\
\hline & Total & & 100.0 & 100.0 & 100 & 100.0 \\
\hline & & & \multicolumn{3}{|c|}{ Chi-square: 0.061} & \\
\hline \multirow[t]{5}{*}{ Females } & Cynicism & High & 50.0 & & 6.9 & 11.8 \\
\hline & & Moderate & & & 27.6 & 23.5 \\
\hline & & Low & 50.0 & 100.0 & 65.5 & 64.7 \\
\hline & Total & & 100.0 & 100.0 & 100.0 & 100.0 \\
\hline & & & \multicolumn{3}{|c|}{ Chi-square: 0.117} & \\
\hline \multirow[t]{5}{*}{ Males } & Personal & High & 55.6 & 36.4 & 11.4 & 23.6 \\
\hline & accomplishment & Moderate & 33.3 & 63.6 & 62.9 & 58.2 \\
\hline & & Low & 11.1 & & 25.7 & 18.2 \\
\hline & Total & & 100.0 & 100.0 & 100.0 & 100.0 \\
\hline & & & \multicolumn{3}{|c|}{ Chi-square: 0.023} & \\
\hline \multirow[t]{5}{*}{ Females } & Personal & High & & & 20.7 & 17.6 \\
\hline & accomplishment & Moderate & 75.0 & & 62.1 & 61.8 \\
\hline & & Low & 25.0 & 100.0 & 17.2 & 20.6 \\
\hline & Total & & 100.0 & 100.0 & 100.0 & 100.0 \\
\hline & & & \multicolumn{3}{|c|}{ Chi-square: 0.285} & \\
\hline
\end{tabular}

Source: Author's calculations. 
Hypothesis 4: There is no significant relationship between working status, level of burnout, and gender.

As Table 5 shows, 10.0 percent of upper white-collar and 4.0 percent of lower white-collar male employees report high emotional exhaustion. Among females, 44.4 percent of upper white-collar, 11.8 percent of lower white-collar, and 25.0 percent of self-employed individuals indicate high emotional exhaustion, which is thus high among females. In the second phase of burnout, males report high levels of cynicism for all job positions while it is also high among self-employed females. Males across all job positions report a high lack of personal accomplishment (28.6 percent), while self-employed females score highest in this category (25 percent). Females score significantly on emotional exhaustion and cynicism, while males score significantly on personal efficacy.

Table 5: Burnout * job position * gender cross-tabulation

\begin{tabular}{|c|c|c|c|c|c|c|c|}
\hline \multirow{2}{*}{\multicolumn{3}{|c|}{ Percentage within job position }} & \multicolumn{4}{|c|}{ Job position } & \multirow{3}{*}{$\frac{\text { Total }}{3.6}$} \\
\hline & & & \multirow[t]{2}{*}{$\begin{array}{c}\text { Self- } \\
\text { employed }\end{array}$} & \multirow{2}{*}{$\begin{array}{c}\begin{array}{c}\text { Upper } \\
\text { white- } \\
\text { collar }\end{array} \\
10.0\end{array}$} & \multirow{2}{*}{$\begin{array}{r}\begin{array}{l}\text { Lower } \\
\text { white- } \\
\text { collar }\end{array} \\
4.0\end{array}$} & \multirow[t]{2}{*}{$\begin{array}{l}\text { Blue- } \\
\text { collar }\end{array}$} & \\
\hline \multirow[t]{5}{*}{ Males } & Emotional & High & & & & & \\
\hline & exhaustion & Moderate & 42.9 & 40.0 & 32.0 & 30.8 & 34.5 \\
\hline & & Low & 57.1 & 50.0 & 64.0 & 69.2 & 61.8 \\
\hline & Total & & 100.0 & 100.0 & 100.0 & 100.0 & 100.0 \\
\hline & & & \multicolumn{3}{|c|}{ Chi-square: 0.861} & & \\
\hline \multirow[t]{5}{*}{ Females } & \multirow{3}{*}{$\begin{array}{l}\text { Emotional } \\
\text { exhaustion }\end{array}$} & High & 25.0 & 44.4 & 11.8 & & 23.5 \\
\hline & & Moderate & 75.0 & 22.2 & 52.9 & & 50.0 \\
\hline & & Low & & 33.3 & 35.3 & & 26.5 \\
\hline & \multirow{2}{*}{\multicolumn{2}{|c|}{ Total }} & 100.0 & 100.0 & 100.0 & & 100.0 \\
\hline & & & Chi-squar & 0.096 & & & \\
\hline \multirow[t]{5}{*}{ Males } & \multirow[t]{3}{*}{ Cynicism } & High & 14.3 & 20.0 & 16.0 & 15.4 & 16.4 \\
\hline & & Moderate & 42.9 & 30.0 & 24.0 & 30.8 & 29.1 \\
\hline & & Low & 42.9 & 50.0 & 60.0 & 53.8 & 54.5 \\
\hline & \multirow{2}{*}{\multicolumn{2}{|c|}{ Total }} & 100.0 & 100.0 & 100.0 & 100.0 & 100.0 \\
\hline & & & Chi-squar & 0.061 & & & \\
\hline \multirow[t]{5}{*}{ Females } & \multirow[t]{3}{*}{ Cynicism } & High & 37.5 & & 5.9 & & 11.8 \\
\hline & & Moderate & 25.0 & 44.4 & 11.8 & & 23.5 \\
\hline & & Low & 37.5 & 55.6 & 82.4 & & 64.7 \\
\hline & \multirow{2}{*}{\multicolumn{2}{|c|}{ Total }} & 100.0 & 100.0 & 100.0 & & 100.0 \\
\hline & & & Chi-squar & 0.979 & & & \\
\hline \multirow[t]{2}{*}{ Males } & \multirow{2}{*}{$\begin{array}{l}\text { Personal } \\
\text { accomplishment }\end{array}$} & High & 28.6 & 10.0 & 16.0 & 46.2 & 23.6 \\
\hline & & Moderate & 71.4 & 40.0 & 68.0 & 46.2 & 58.2 \\
\hline
\end{tabular}




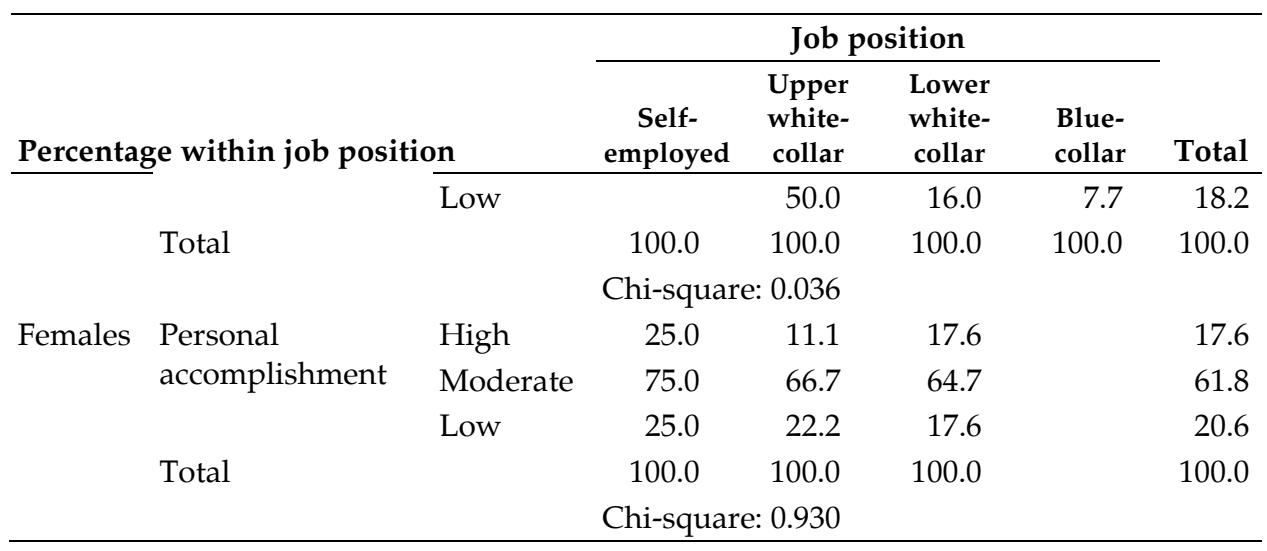

Source: Author's calculations.

Hypothesis 5: There is no significant relationship between work experience, level of burnout, and gender.

Table 6 shows that emotional exhaustion is highest among males with the least work experience- $-0-4$ years (7.1 percent) and 5-10 years (7.7 percent). It is highest among females with 11-16 years' work experience (40 percent) and 11.1 percent and 21.1 percent for 5-10 and 0-4 years' work experience, respectively. Males report high cynicism corresponding to work experience of $0-4$ years (21.4 percent), 5-10 years (23.1 percent), 11-16 years (14.3 percent), and 17-24 years (12.5 percent), while females score less than males across 0-16 years of work experience. Lack of personal accomplishment is highest (62.5 percent) among males with 17-24 years' work experience. Females with work experience of 0-4 years score highest (28.3 percent) in this category. Males score significantly on emotional exhaustion, cynicism, and personal efficacy.

Table 6: Burnout * work experience * gender cross-tabulation

\begin{tabular}{|c|c|c|c|c|c|c|c|c|}
\hline & & & \multicolumn{5}{|c|}{ Work experience (years) } & \multirow[b]{2}{*}{ Total } \\
\hline \multicolumn{3}{|c|}{ Percentage within work experience } & $0-4$ & $5-10$ & $11-16$ & $17-24$ & $25-50$ & \\
\hline \multirow[t]{5}{*}{ Males } & \multirow{3}{*}{$\begin{array}{l}\text { Emotional } \\
\text { exhaustion }\end{array}$} & High & 7.1 & 7.7 & & & & 3.6 \\
\hline & & Moderate & 42.9 & 61.5 & 35.7 & & & 34.5 \\
\hline & & Low & 50.0 & 30.8 & 64.3 & 100.0 & 100.0 & 61.8 \\
\hline & \multirow{2}{*}{\multicolumn{2}{|c|}{ Total }} & 100.0 & 100.0 & 100.0 & 100.0 & 100.0 & 100.0 \\
\hline & & & hi-squ & re: 0.04 & & & & \\
\hline \multirow[t]{3}{*}{ Females } & \multirow{3}{*}{$\begin{array}{l}\text { Emotional } \\
\text { exhaustion }\end{array}$} & High & 21.1 & 11.1 & 40.0 & & 100.0 & 23.5 \\
\hline & & Moderate & 47.4 & 66.7 & 40.0 & & & 50.0 \\
\hline & & Low & 31.6 & 22.2 & 20.0 & & & 26.5 \\
\hline
\end{tabular}




\begin{tabular}{|c|c|c|c|c|c|c|c|c|}
\hline \multirow{2}{*}{\multicolumn{3}{|c|}{ Percentage within work experience }} & \multicolumn{5}{|c|}{ Work experience (years) } & \multirow[b]{2}{*}{ Total } \\
\hline & & & \multirow[b]{2}{*}{100.0} & \multirow{2}{*}{$\begin{array}{l}\mathbf{5 - 1 0} \\
100.0\end{array}$} & \multirow{2}{*}{$\frac{\mathbf{1 1 - 1 6}}{100.0}$} & \multirow[t]{2}{*}{$17-24$} & \multirow{2}{*}{$\begin{array}{r}\mathbf{2 5 - 5 0} \\
100.0\end{array}$} & \\
\hline & Total & & & & & & & 100.0 \\
\hline & & & Chi-squ & are: 0.4 & & & & \\
\hline \multirow[t]{5}{*}{ Males } & Cynicism & High & 21.4 & 23.1 & 14.3 & 12.5 & & 16.4 \\
\hline & & Moderate & 57.1 & 30.8 & 21.4 & 12.5 & & 29.1 \\
\hline & & Low & 21.4 & 46.2 & 64.3 & 75.0 & 100.0 & 54.5 \\
\hline & Total & & 100.0 & 100.0 & 100.0 & 100.0 & 100.0 & 100.0 \\
\hline & & & \multicolumn{5}{|c|}{ Chi-square: 0.073} & \\
\hline \multirow[t]{5}{*}{ Females } & Cynicism & High & 5.3 & 11.1 & 20.0 & & 100.0 & 11.8 \\
\hline & & Moderate & 26.3 & 22.2 & 20.0 & & & 23.5 \\
\hline & & Low & 68.4 & 66.7 & 60.0 & & & 64.7 \\
\hline & Total & & 100.0 & 100.0 & 100.0 & & 100.0 & 100.0 \\
\hline & & & \multicolumn{5}{|c|}{ Chi-square: 0.195} & \\
\hline \multirow[t]{5}{*}{ Males } & Personal & High & 14.3 & & 28.6 & 62.5 & 33.3 & 23.6 \\
\hline & accomplishment & Moderate & 71.4 & 61.5 & 50.0 & 37.5 & 66.7 & 58.2 \\
\hline & & Low & 14.3 & 38.5 & 21.4 & & & 18.2 \\
\hline & Total & & 100.0 & 100.0 & 100.0 & 100.0 & 100.0 & 100.0 \\
\hline & & & \multicolumn{5}{|c|}{ Chi-square: 0.042} & \\
\hline \multirow[t]{5}{*}{ Females } & Personal & High & 28.3 & 11.1 & & & & 17.6 \\
\hline & accomplishment & Moderate & 57.9 & 66.7 & 60.0 & & 100.0 & 61.8 \\
\hline & & Low & 15.8 & 22.2 & 40.0 & & & 20.6 \\
\hline & Total & & 100.0 & 100.0 & 100.0 & & 100.0 & 100.0 \\
\hline & & & \multicolumn{5}{|c|}{ Chi-square: 0.710} & \\
\hline
\end{tabular}

Source: Author's calculations.

Hypothesis 6: There is no significant relationship between marital status, level of burnout, and gender.

As Table 7 shows, 12.5 percent of unmarried males report high emotional exhaustion while 21.4 percent of unmarried females, compared to 33 percent of married females, indicate the same. Cynicism is higher among unmarried males (18.8 percent) than married males (15.4 percent), while 14.3 percent of unmarried females also report feeling a high level of cynicism. Lack of personal accomplishment is higher among married males (30.8 percent) than among unmarried males (6.3 percent). More unmarried females rate their sense of accomplishment negatively (17.9 percent) than married females (16.7 percent). The chi-square term reveals that males score significantly on emotional exhaustion, cynicism, and personal efficacy. 
Table 7: Burnout * marital status * gender cross-tabulation

\begin{tabular}{|c|c|c|c|c|c|}
\hline \multirow{2}{*}{\multicolumn{3}{|c|}{ Percentage within marital status }} & \multicolumn{2}{|c|}{ Marital status } & \multirow{3}{*}{$\frac{\text { Total }}{3.6}$} \\
\hline & & & \multirow[t]{2}{*}{ Married } & \multirow{2}{*}{$\frac{\text { Unmarried }}{12.5}$} & \\
\hline \multirow[t]{5}{*}{ Males } & \multirow{3}{*}{$\begin{array}{l}\text { Emotional } \\
\text { exhaustion }\end{array}$} & High & & & \\
\hline & & Moderate & 28.2 & 50.0 & 34.5 \\
\hline & & Low & 71.8 & 37.5 & 61.8 \\
\hline & \multirow{2}{*}{\multicolumn{2}{|c|}{ Total }} & 100.0 & 100.0 & 100.0 \\
\hline & & & Chi-square: .014 & & \\
\hline \multirow[t]{5}{*}{ Females } & \multirow{3}{*}{$\begin{array}{l}\text { Emotional } \\
\text { exhaustion }\end{array}$} & High & 33.3 & 21.4 & 23.5 \\
\hline & & Moderate & 50.0 & 50.0 & 50.0 \\
\hline & & Low & 16.7 & 28.6 & 26.5 \\
\hline & \multirow{2}{*}{\multicolumn{2}{|c|}{ Total }} & 100.0 & 100.0 & 100.0 \\
\hline & & & Chi-square: 0.755 & & \\
\hline \multirow[t]{5}{*}{ Males } & \multirow[t]{3}{*}{ Cynicism } & High & 15.4 & 18.8 & 16.4 \\
\hline & & Moderate & 15.4 & 62.5 & 29.1 \\
\hline & & Low & 69.2 & 18.8 & 54.5 \\
\hline & \multirow{2}{*}{\multicolumn{2}{|c|}{ Total }} & 100.0 & 100.0 & 100.0 \\
\hline & & & Chi-square: 0.073 & & \\
\hline \multirow[t]{5}{*}{ Females } & \multirow[t]{3}{*}{ Cynicism } & High & & 14.3 & 11.8 \\
\hline & & Moderate & 50.0 & 17.9 & 23.5 \\
\hline & & Low & 50.0 & 67.9 & 64.7 \\
\hline & \multirow{2}{*}{\multicolumn{2}{|c|}{ Total }} & 100.0 & 100.0 & 100.0 \\
\hline & & & Chi-square: 0.195 & & \\
\hline \multirow[t]{5}{*}{ Males } & \multirow{3}{*}{$\begin{array}{l}\text { Personal } \\
\text { accomplishment }\end{array}$} & High & 30.8 & 6.3 & 23.6 \\
\hline & & Moderate & 48.7 & 81.3 & 58.2 \\
\hline & & Low & 20.5 & 12.5 & 18.2 \\
\hline & \multirow{2}{*}{\multicolumn{2}{|c|}{ Total }} & 100.0 & 100.0 & 100.0 \\
\hline & & & Chi-square: 0.069 & & \\
\hline \multirow[t]{5}{*}{ Females } & \multirow{3}{*}{$\begin{array}{l}\text { Personal } \\
\text { accomplishment }\end{array}$} & High & 16.7 & 17.9 & 17.6 \\
\hline & & Moderate & 50.0 & 64.3 & 61.8 \\
\hline & & Low & 33.3 & 17.9 & 20.6 \\
\hline & \multirow{2}{*}{\multicolumn{2}{|c|}{ Total }} & 100.0 & 100.0 & 100.0 \\
\hline & & & Chi-square: 0.690 & & \\
\hline
\end{tabular}

Source: Author's calculations.

Hypothesis 7: There is no significant relationship between household income, level of burnout, and gender.

Table 8 shows that males earning more than PKR 25,000 report high emotional exhaustion (11.1 and 5.6 percent), whereas females from the lowest income group (50 percent) indicate high emotional exhaustion. Females earning PKR 10,000 and above report lower emotional exhaustion 
(23.1, 20.0, and 33.3 percent). Males with an income above PKR 25,000 report cynicism (22.2 percent), while fewer with a smaller income do so (18.2 percent earning PKR 5,000 and 18.8 percent earning PKR 10,000). There is higher cynicism among females with an income level of PKR 5,000 (20 percent) and PKR 10,000 (23.1 percent). A high lack of efficacy is found among males with an income level of PKR 5,000 (45.5 percent), which decreases progressively (25 percent at PKR 10,000, and 16.7 percent at PKR $40,000)$ indicating that males with a higher income level feel less need to gain a sense of personal accomplishment. Among females, lack of personal efficacy is highest at an income level of PKR 5,000 (50 percent), decreasing to 20 percent at PKR 25,000-40,000. The chi-square is insignificant for all levels of burnout.

\section{Table 8: Burnout * household income * gender cross-tabulation}

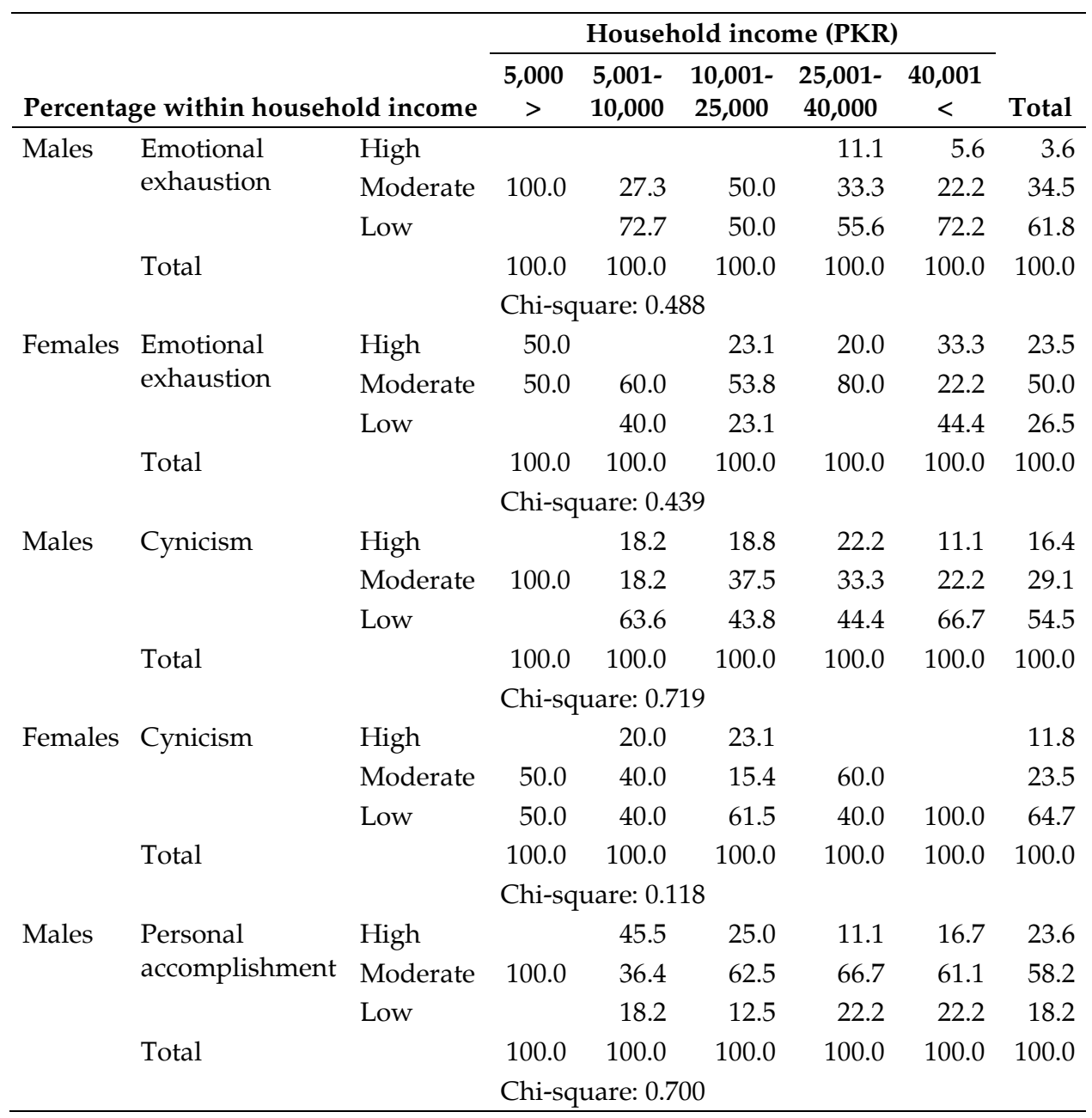




\begin{tabular}{|c|c|c|c|c|c|c|c|c|}
\hline \multirow{2}{*}{\multicolumn{3}{|c|}{ Percentage within household income }} & \multicolumn{5}{|c|}{ Household income (PKR) } & \multirow[b]{2}{*}{ Total } \\
\hline & & & \multirow{2}{*}{$\begin{array}{c}5,000 \\
> \\
50.0\end{array}$} & \multirow{2}{*}{$\begin{array}{r}5,001- \\
10,000 \\
20.0\end{array}$} & \multirow{2}{*}{$\begin{array}{r}\begin{array}{c}10,001- \\
25,000\end{array} \\
23.1\end{array}$} & \multirow{2}{*}{$\begin{array}{r}25,001- \\
40,000 \\
20.0\end{array}$} & \multirow[t]{2}{*}{$\begin{array}{c}40,001 \\
<\end{array}$} & \\
\hline Females & Personal & High & & & & & & 17.6 \\
\hline & accomplishment & Moderate & 50.0 & 60.0 & 61.5 & 60.0 & 66.7 & 61.8 \\
\hline & & Low & & 20.0 & 15.4 & 20.0 & 33.3 & 20.6 \\
\hline & Total & & 100.0 & 100.0 & 100.0 & 100.0 & 100.0 & 100.0 \\
\hline & & & Chi-sq & uare: 0.8 & & & & \\
\hline
\end{tabular}

Source: Author's calculations.

Hypothesis 8: There is no significant relationship between sector, level of burnout, and gender.

As Table 9 indicates, males employed in the public sector are subject to high emotional exhaustion (6.75 percent) compared to 2.5 percent in the private sector. Among females, 27 percent working in the public sector report high emotional exhaustion compared to 21 percent in the private sector. Cynicism is higher among males in the public sector (20 percent) than in the private sector (15 percent), and a similar trend applies to females with 18.2 percent for the public sector and 8.7 percent for the private sector. A larger proportion of males in the private sector report a high lack of personal accomplishment ( 25 percent) than in the public sector ( 20 percent). Females working in the public sector, however, indicate a high lack of personal accomplishment (36.4 percent) compared to 8.7 percent in the private sector. This implies that males in the public sector and females in the private sector are more driven than their counterparts in the private and public sectors, respectively. However, burnout is higher in the public sector than in the private sector. Neither the public nor private sector is significant.

Table 9: Burnout * sector * gender cross-tabulation

\begin{tabular}{lllccc}
\hline & & \multicolumn{2}{c}{ Sector } & \\
\cline { 3 - 4 } Percentage within sector & & Public & Private & Total \\
\hline \multirow{2}{*}{ Males } & Emotional & High & 6.7 & 2.5 & 3.6 \\
& exhaustion & Moderate & 40.0 & 32.5 & 34.5 \\
& Low & 53.3 & 65.0 & 61.8 \\
\cline { 3 - 4 } Total & & 100.0 & 100.0 & 100.0 \\
& & & Chi-square: 0.625 & \\
& Emales & High & 27.3 & 21.7 & 23.5 \\
& exhaustion & Moderate & 63.6 & 43.5 & 50.0 \\
& & Low & 9.1 & 34.8 & 26.5 \\
& Total & & 100.0 & 100.0 & 100.0 \\
\hline
\end{tabular}




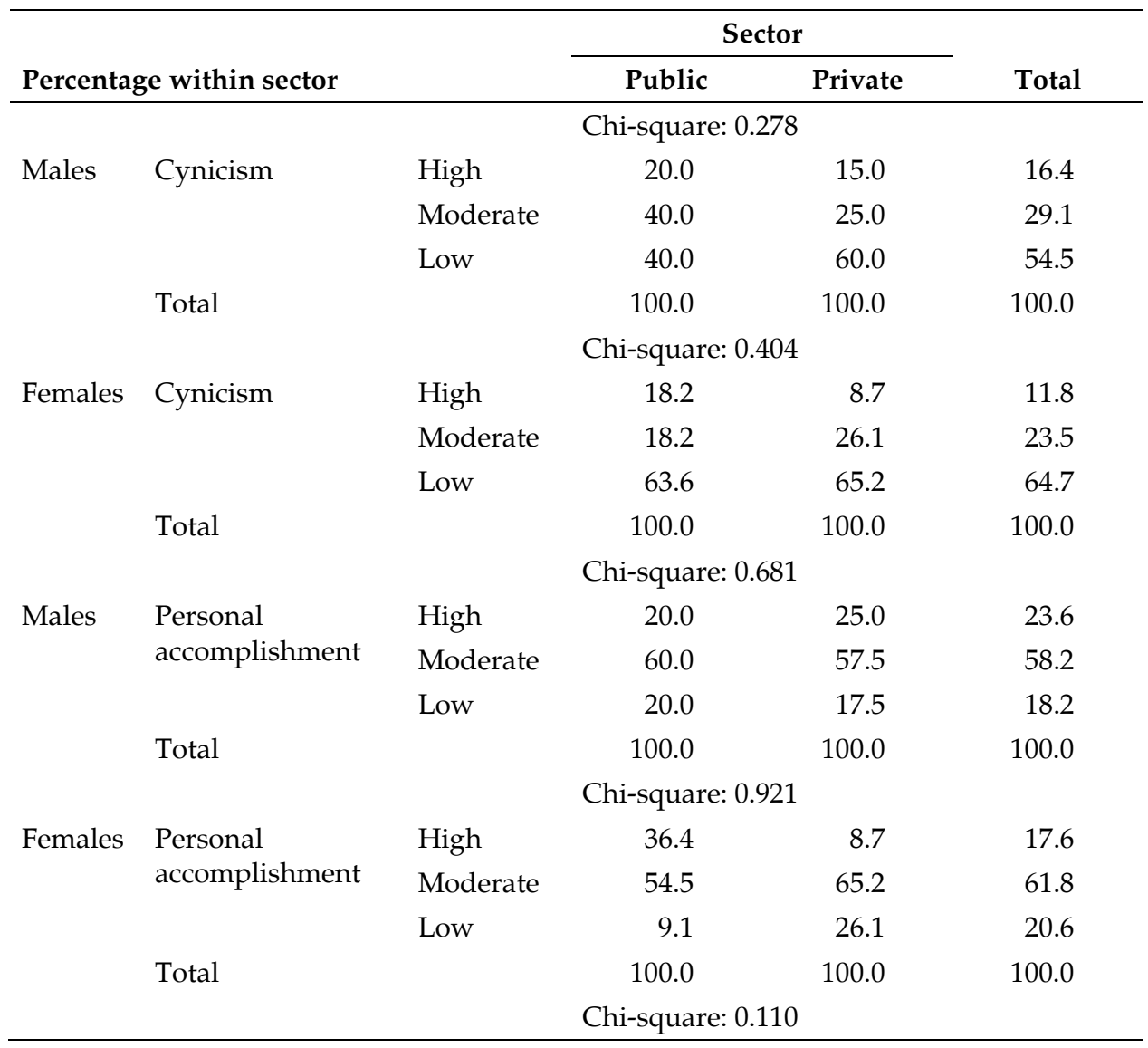

Source: Author's calculations.

Hypothesis 9: There is no significant relationship between industry, level of burnout, and gender

Table 10 shows that, for males, emotional exhaustion is highest in the services sector (12.5 percent), while for females it is highest in the manufacturing sector (60 percent), followed by 33.3 percent in services, 20.0 percent in education, and 12.5 percent in social services. Males employed in the services sector report the highest level of cynicism (31.3 percent), followed by 25 percent in hospitals, 20.0 percent in banking, and 4.5 percent in manufacturing. For females, cynicism is highest among employees in the manufacturing sector (40 percent) followed by the services sector (33.3 percent). Lack of personal accomplishment is highest in the manufacturing sector (40 percent) for males, followed by 25 percent in hospitals, and 12.5 percent in services. Females score highest in the education sector (30 percent) in this category, followed by manufacturing (20 percent), and 12.5 percent in services. The chi-square is only significant for cynicism. 
Table 10: Burnout * industry * gender cross-tabulation

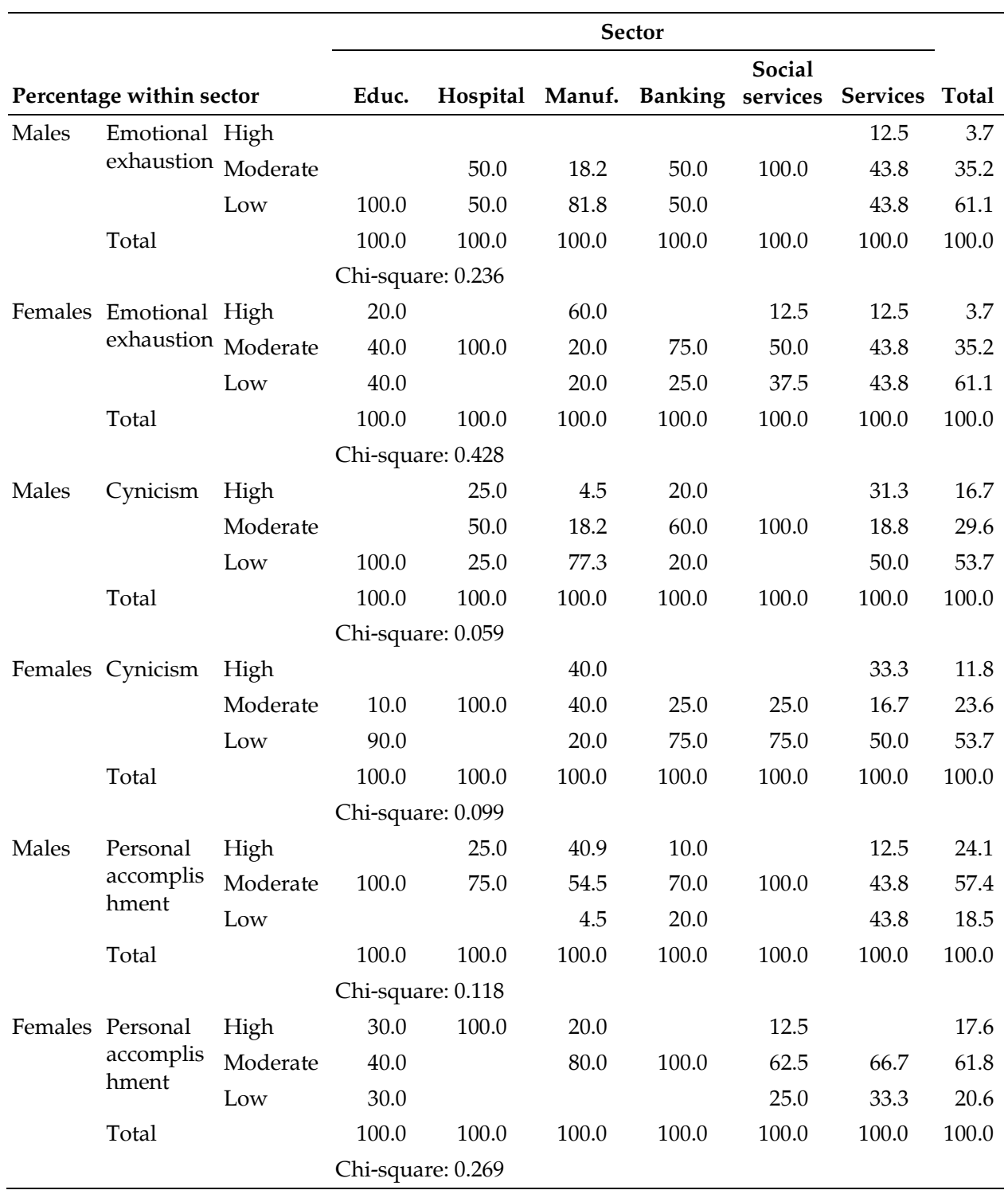

Source: Author's calculations.

Hypothesis 10: There is no significant relationship between role ambiguity and gender.

Table 11 shows that 20 percent of males report positive indications of role ambiguity compared to 11 percent of females. Around 60 percent of males and 61.85 percent of females feel clear about their job roles. The chisquare is insignificant. 
Table 11: Gender and role ambiguity

\begin{tabular}{llccc}
\hline & & \multicolumn{2}{c}{ Gender } & \\
\cline { 2 - 4 } \multicolumn{1}{c}{ Percentage within gender } & Males (\%) & Females (\%) & Total (\%) \\
\hline My work is prioritized; & Yes & 65.5 & 61.8 & 64.0 \\
not everything is an & No opinion & 14.5 & 26.5 & 19.1 \\
"emergency." & No & 20.0 & 11.8 & 16.9 \\
Total & \multicolumn{1}{c}{100.0} & 100.0 & 100.0 \\
& & Chi-square: 0.296 & \\
\hline
\end{tabular}

Source: Author's calculations.

Hypothesis 11: There is no significant relationship between role conflict and gender.

As Table 12 indicates, around 50.9 percent of males agree that they are subject to role conflict; this figure is smaller for females (44.1 percent). About 25.5 percent of males and 20.6 percent of females do not feel they are caught up in role conflict. The chi-square is insignificant.

Table 12: Gender and role conflict

\begin{tabular}{llccc}
\hline & & \multicolumn{2}{c}{ Gender } & \\
\cline { 2 - 4 } \multicolumn{2}{l}{ Percentage within gender } & Males (\%) & Females (\%) & Total (\%) \\
\hline I get mixed messages & Yes & 50.9 & 44.1 & 48.3 \\
from different people & No opinion & 23.6 & 35.3 & 28.1 \\
$\begin{array}{l}\text { about what I should be } \\
\text { doing with my time. }\end{array}$ & No & 25.5 & 20.6 & 23.6 \\
Total & & 100.0 & 100.0 & 100.0 \\
& & Chi-square: 0.490 & \\
\hline
\end{tabular}

Source: Author's calculations.

Hypothesis 12: There is no significant relationship between work overload and gender.

Table 13 indicates that 64.7 percent of females and 41.8 percent of males feel they are overloaded by work at their jobs, while 43.6 percent of males and 26.5 percent of females disagreed. The chi-square is insignificant. 
Table 13: Work overload and gender

\begin{tabular}{llccc}
\hline & & \multicolumn{2}{c}{ Gender } & \\
\cline { 2 - 4 } \multicolumn{2}{l}{ Percentage within gender } & Males (\%) & Females (\%) & Total (\%) \\
\hline I have too much work & Yes & 41.8 & 64.7 & 50.6 \\
to complete in the & No opinion & 14.5 & 8.8 & 12.4 \\
given timeframe. & No & 43.6 & 26.5 & 37.1 \\
\multirow{2}{*}{ Total } & & 100.0 & 100.0 & 100.0 \\
& & \multicolumn{2}{c}{ Chi-square: 0.111} \\
\hline
\end{tabular}

Source: Author's calculations.

Hypothesis 13: There is no significant relationship between organizational politics and gender.

Table 14 shows that 36.4 percent of males report that organizational politics interfere in their work; among females, this figure is smaller (29.4 percent). The chi-square is not significant.

Table 14: Organizational politics and gender

\begin{tabular}{llccr}
\hline & & \multicolumn{2}{c}{ Gender } & \\
\cline { 2 - 4 } \multicolumn{2}{l}{ Percentage within gender } & Males (\%) & Females (\%) & Total \\
\hline Organizational politics & Yes & 36.4 & 29.4 & 33.7 \\
interfere with my & No opinion & 20.0 & 26.5 & 22.5 \\
work. & No & 43.6 & 44.1 & 43.8 \\
Total & \multicolumn{1}{c}{100.0} & 100.0 & 100.0 \\
& & \multicolumn{2}{c}{ Chi-square: 0.707} \\
\hline
\end{tabular}

Source: Author's calculations.

Hypothesis 14: There is no significant relationship between autonomy and gender.

As Table 15 shows, 80 percent of males and 73.5 percent of females say they have autonomy at work. Around 11 percent of the sample contends that they do not have enough autonomy and flexibility at work. The chi-square is insignificant for autonomy with regard to gender. 
Table 15: Autonomy and gender

\begin{tabular}{llccc}
\hline & & \multicolumn{2}{c}{ Gender } & \\
\cline { 2 - 4 } \multicolumn{2}{l}{ Percentage within gender } & Males (\%) & Females (\%) & Total (\%) \\
\hline I participate in & Yes & 80.9 & 73.5 & 77.5 \\
decisions about how I & No opinion & 10.9 & 14.7 & 12.4 \\
do my work & No & 9.1 & 11.8 & 10.1 \\
\multirow{2}{*}{ Total } & & 100.0 & 100.0 & 100.0 \\
& & \multicolumn{2}{c}{ Chi-square: 0.776 } \\
\hline
\end{tabular}

Source: Author's calculations.

\subsection{Results}

We have investigated the level of burnout in relation to different socio-demographic factors in a Lahore city population study. As a threedimensional syndrome, it is difficult to determine which factor affects burnout, but the level of burnout can be easily assessed. Women score significantly on emotional exhaustion while males score higher on cynicism and lack of personal accomplishment compared to other sociodemographics. Education and work experience are strongly associated with females while age and income are significant factors for males.

Women's higher burnout scores are related to higher levels of education (graduates) and less work experience (0-10 years) and smaller income levels (PKR 10,000-25,000), age (24-35 years), being self-employed, and working in the manufacturing sector. Among men, burnout is related to white-collar (upper and lower) employee positions, work experience of 0-4 years, income levels of PKR 25,000 and over, and working in the services sector. Burnout is significant among males compared to females with regard to marital status. With regard to job stressors, males and females are not significantly different in their responses to role ambiguity, role conflict, organizational politics, autonomy, and work overload.

\section{Discussions and Conclusion}

\subsection{Discussion}

In contrast to our findings, in the literature burnout is positively related to age (Birch et al., 1996; Mor \& Laliberte, 1984; Poulin \& Walter, 1993; Bakker et al., 2002). There may be several reasons for this. First, in Lahore, individuals may face 'early career burnout' and reality shocks (Cherniss, 1980). Reality shocks are explained by the breakdown of 
perception that exists in an individual before he/she is exposed to a working environment. The MBI manual shows a decline in burnout levels with age or work experience for all three dimensions (Maslach et al., 1996).

Overall, women score higher on emotional exhaustion while men score higher on cynicism. This finding is supported by Vredenburgh et al. (1999) and Schaufeli and Enzmann (1998). We also find higher burnout among unmarried males and females, and among those with higher levels of education and those employed in the services sector. According to Schaufeli and Enzmann (1998), a higher risk of burnout is associated with being unmarried and having a higher level of education. Graduates scored higher on personal accomplishment, while marital status was significantly related to emotional exhaustion. In contrast, people who were single or divorced scored higher than those who were married, as shown by Maslach et al. (2001). We found differences by level of education for each of the MBI subscales. Higher levels of education were associated with higher scores for emotional exhaustion while the reverse pattern emerged for depersonalization.

Burnout has been extensively investigated in services-based industries, especially healthcare and teaching (see Khattak, Khan, Haq, Arif, \& Minhas, 2011; Schaufeli \& Buunk, 2005; Gundersen, 2001; Rutter et al., 2002). According to this research, females working in the manufacturing sector are more prone to burnout while males employed in the services industry are more vulnerable to burnout. This argument is supported by several studies on burnout in healthcare (Felton, 1998) and education (Brouwers \& Tomic, 2000; Burke et al., 1996; Mazur \& Lynch, 1989), where the burnout level was higher than in other occupations. Among men, burnout is associated with white-collar (upper and lower) employee positions. Toppinen-Tanner et al. (2002) find that there are no differences between white-collar and blue-collar employees in the process of burnout while the work-related precursors of burnout (i.e., job stressors) are very similar for both groups.

\subsection{Study Limitations}

The research on burnout is subject to certain limitations. First, employees who are highly burnt out tend to avoid filling in questionnaires, due to which the level of burnout falls to between low and moderate, indicating that employees have scored higher on the first and/or second dimensions of burnout. Second, this research was based on a crosssectional setting. It was difficult to take the cohort effect and the actual 
development of the work career into consideration, which could have been done with the use of longitudinal data.

Burnout among different socio-demographic factors has not been analyzed. A multivariate analysis could help to compare across demographics. Lastly, our sample consisted of 100 respondents while that of other nationwide studies has varied from below 100 to 5,000 or more. Although, as the MBI manual (1997) explains, in any sample only fewer than 50 respondents are likely to be burnt out out, further nationwide research is required to better understand the nature of burnout prevailing in Pakistan.

\subsection{Conclusion}

In this domestic representative study, burnout is associated with various factors. Males are more prone to burnout. Age does not protect against burnout particularly among males who experience greater burnout at an early age (24-29 years). Higher education levels and less work experience carry a greater risk of burnout for working women, whereas men with white-collar jobs and jobs in the services sector are subject to a greater risk of burnout.

More research is needed especially in the area of blue-collar workers with low education. Our results show that burnout is a relevant concern and a key area of study in all kinds of vocational groups. The risk factors can vary for different subgroups and this should be taken into account in planning future research. 


\section{References}

Ahola, K., Honkonen, T., Isometsä, E., Kalimo, R., Nykyri, E., Koskinen, S., et al. (2005). Burnout in the general population: Results from the Finnish Health 2000 Study. Social Psychiatry and Psychiatric Epidemiology, 41, 11-17.

Bakker, A. B., Demerouti, E., \& Schaufeli, W. B. (2002). Validation of the Maslach Burnout Inventory - General Survey: An Internet study. Anxiety, Stress, and Coping, 15, 245-260.

Beurskens, A. J. H. M., Bültmann, U., Kant, I., Vercoulen, J. H. M. M., \& Bleijenberg, G., \& Swaen, G. M. H. (2002). Fatigue among working people: Validity of a questionnaire measure. Occupational and Environmental Medicine, 57, 353-357.

Birch, N., Marchant, M. P., \& Smith, N. M. (1986). Perceived role conflict, role ambiguity, and reference librarian burnout in public libraries. Library and Information Science Research, 8, 53-65.

Brouwers, A., \& Tomic, W. (2000). A longitudinal study of teacher burnout and perceived self-efficacy in classroom management. Teaching and Teacher Education, 16(2), 239-253.

Burke, R. J., Greenglass, E. R., \& Schwarzer, R. (1996). Predicting teacher burnout over time: Effects of work stress, social support, and selfdoubts on burnout and its consequences. Anxiety, Stress, and Coping, 9, 261-275.

Cherniss, C. (1980). Professional burnout in human service organizations. New York, NY: Praeger.

Cherniss, C. (1993). Role of professional self-efficacy in the etiology and amelioration of burnout. In W. B. Schaufeli, C. Maslach, \& T. Marek (Eds.), Professional burnout: Recent developments in theory and research (pp. 135-149). Washington, DC: Taylor \& Francis.

Cordes, C. L., \& Dougherty, T. W. (1993). A review and an integration of research on job burnout. Academy of Management Review, 18(4), 621-656.

Felton, J. S. (1998). Burnout as a clinical entity: Its importance in healthcare workers. Occupational Medicine, 48(4), 237-250. 
Freudenberger, H. J. (1974). Staff burnout. Journal of Social Issues, 30, 159-165.

Freudenberger, H. J. (1975). The staff burnout syndrome in alternative institutions. Psychotherapy: Theory, Research and Practice, 12(1), 72-83.

Gaines, J., \& Jermier, J. M. (1983). Emotional exhaustion in a high-stress organization. Academy of Management Journal, 26, 567-586.

Geurts, S., Rutte, C., \& Peeters, M. (1999). Antecedents and consequences of work-home interference among medical residents. Social Science and Medicine, 48, 1135-1148.

Golembiewski, R. T., Boudreau, R. A., Sun, B., \& Luo, H. (1998). Estimates of burnout in public agencies: Worldwide, how many employees have which degrees of burnout, and with what consequences? Public Administration Review, 58(1), 59-65.

Gundersen, L. (2001). Physician burnout. Annals of Internal Medicine, 135(2), 145-148.

Jackson, S. E. (1983). Participation in decision-making as a strategy for reducing job-related strain. Journal of Applied Psychology, 68(1), 3-19.

Jackson, S. E., Schwab, R. L., \& Schuler, R. S. (1986). Toward an understanding of the burnout phenomenon. Journal of Applied Psychology, 71, 630-640.

Jackson, S. E., Turner, J. A., \& Brief, A. P. (1987). Correlates of burnout among public service lawyers; summary. Journal of Occupational Behavior, 8, 339-349.

Khattak, J. K., Khan, M. A., Haq, A. U., Arif, M. \& Minhas, A. A. (2011). Occupational stress and burnout in Pakistan's banking sector. African Journal of Business Management, 5(3), 810-817.

Kirk-Brown, A., \& Wallace, D. (2004). Predicting burnout and job satisfaction in workplace counselors: The influence of role stressors, job challenge, and organizational knowledge. Journal of Employment Counseling, 41(1), 29-38.

Koeske, G. F., \& Koeske, R. D. (1989). Construct validity of the Maslach Burnout Inventory: A critical review and reconceptualization. Journal of Applied Behavioral Sciences, 25, 131-144. 
Leiter, M. P. (1991). Coping patterns as predictors of burnout: The function of control and escapist coping patterns. Journal of Organizational Behavior, 12(2), 123-144.

Leiter, M. P., \& Maslach, C. (1988). The impact of interpersonal environment on burnout and organizational commitment. Journal of Organizational Behavior, 9(4), 297-309.

Leiter, M. P., \& Maslach, C. (2004). Areas of work life: A structured approach to organizational predictors of job burnout. In P. Perrewe' \& D. C. Ganster (Eds.), Research in occupational stress and wellbeing (vol. 3): Emotional and physiological processes and positive intervention strategies (pp. 91-134). Oxford, UK: JAI Press/Elsevier.

Maslach, C. (1982). Burnout: The cost of caring. Englewood Cliffs, NJ: Prentice-Hall.

Maslach, C., \& Jackson, S. E. (1981). Maslach Burnout Inventory (research edition). Palo Alto, CA: Consulting Psychologists Press.

Maslach, C., \& Jackson, S. E. (1986). MBI: Maslach Burnout Inventory (manual research edition). Palo Alto, CA: Consulting Psychologists Press.

Maslach, C., \& Schaufeli, W. B (1993). Historical and conceptual development of burnout. In W. Schaufeli, C. Maslach, \& T. Marek (Eds.), Professional burnout: Recent developments in theory and research (pp. 1-18). Washington, DC: Taylor \& Francis.

Maslach, C., Jackson, S. E., \& Leiter, M. P. (1996). Maslach Burnout Inventory manual (3rd ed.). Palo Alto, CA: Consulting Psychologists Press.

Maslach, C., Schaufeli, W. B., \& Leiter, M. P. (2001). Job burnout. Annual Review of Psychology, 52, 397-422.

Matthews, D. B. (1999). A comparison of burnout in selected occupational fields. The Career Development Quarterly, 38(3), 230-239.

Mazur, P. J., \& Lynch, M. D. (1989). Differential impact of administrative, organizational, and personality factors on teacher burnout. Teaching and Teacher Education, 5(4), 337-353.

Mor, V., \& Laliberte, L. (1984). Burnout among hospice staff. Health and Social Work, 9(4), 274-283. 
Pines, A., Aronson, E., \& Kafry, D. (1981). Burnout: From tedium to personal growth. New York, NY: The Free Press.

Poulin J. E., \& Walter C. A. (1993). Burnout in gerontological social work. Social Work, 38, 305-310.

Price, L., \& Spence, S. H. (1994). Burnout symptoms amongst drug and alcohol service employees: Gender differences in the interaction between work and home stressors. Anxiety, Stress, and Coping, 7, $67-84$.

Rizzo, J. R., House, R. J., \& Lirtzman, S. I. (1970). Role conflict and ambiguity in complex organizations. Administrative Science Quarterly, 15, 150-163.

Rutter, H., Herzberg, J., \& Paice, E. (2002). Stress in doctors and dentists who teach. Medical Education, 36(6), 543-549.

Sanders, J. C., Fulks, D. L., \& Knoblett, J. K. (1995). Stress and stress management in public accounting. The CPA Journal, 65(8), 46-49.

Sargent, M. C., Sotile, W., Sotile, M. O., Rubash, H., \& Barrack, R. L. (2004) Stress and coping among orthopaedic surgery residents and faculty. Journal of Bone E Joint Surgery, American Volume, 86A(7), 1579-1586.

Schaufeli, W. B. (2003). Past performance and future perspectives of burnout research. South African Journal of Industrial Psychology, 29(4), 1-15.

Schaufeli, W. B., \& Bakker, A. B. (2004). Job demands, job resources, and their relationship with burnout and engagement: A multi-sample study. Journal of Organizational Behavior, 25(3), 293-315.

Schaufeli, W. B., \& Buunk, B. P. (2005). The handbook of work and health psychology (2nd ed.). Chichester, UK: Wiley.

Schaufeli, W. B., \& Enzmann, D. (1998). The burnout companion to study and practice: A critical analysis. London, UK: Taylor \& Francis.

Schaufeli, W. B., Bakker, A. B., \& Van Rhenen, W. (2009). How changes in job demands and resources predict burnout, work engagement, and sickness absenteeism. Journal of Organizational Behavior, 30, 893-917. 
Schaufeli, W. B., Leiter, M. P., \& Maslach, C. (2008). Burnout: 35 years of research and practice. Career Development International, 14(3), 204-220.

Toppinen-Tanner, S., Kalimo, R., \& Mutanen, P. (2002). The process of burnout in white-collar and blue-collar jobs: Eight-year prospective study of exhaustion. Journal of Organizational Behavior, 23(5), 555-570.

Tripathy, M. M. (2002). Burnout stress syndrome in managers. Management and Labor Studies, 27(2), 89-114.

Van der Colff, J. J., \& Rothmann, S. (2009). Occupational stress, sense of coherence, coping, burnout and work engagement of registered nurses in South Africa. South African Journal of Industrial Psychology, 35(1), 1-10.

Van Horn, J. E., Schaufeli, W. B., Greenglass, E. R., \& Burke, R. J. (1997). A Canadian-Dutch comparison of teachers' burnout. Psychological Reports, 81, 371-382.

Vredenburgh, L. D., Carlozzi, A. F., \& Stein, L. B. (1999). Burnout in counseling psychologists: Type of practice setting and pertinent demographics. Counselling Psychology Quarterly, 12, 293-302.

Yip, B., \& Rowlinson, S. (2007, May). The crossover of burnout and engagement. Paper presented at the CIB World Building Congress on Construction and Development, Cape Town, South Africa. 